\title{
Factors That Influence Word of Mouth Behavior in Fast Food Restaurants
}

\author{
Theodorus Dharma Wibisono, Nico Lukito* \\ Magister Management Program, Post Graduate Studies \\ Trisakti University \\ Jakarta, Indonesia \\ *nicolukito@trisakti.ac.id
}

\begin{abstract}
This study aims to determine the Effect of Food Quality, Personal Interaction Quality, Physical Environment Quality, Perceived Value to Word of Mouth Intention via Customer Experience, Trust, and Commitment in customer of fast food fried chicken restaurant in Jakarta. This study involved 217 customers of fast food fried chicken restaurant in Jakarta. This research using quantitative approach. Data analysis techniques used in this research is using SEM (Structural Equation Modeling). Based on the results of hypothesis testing found WOM intention is influenced by commitment, then commitment is influenced by trust and customer experience, where customer experience is influenced by food quality and perceived value.
\end{abstract}

Keywords-food quality, personal interaction quality, physical environment quality, perceived value, word of mouth intention customer experience, trust, commitment, fast food fried chicken restaurant

\section{INTRODUCTION}

Fast food restaurant is an industry whose development is fast, especially in urban areas, which incidentally has a routinely and rhythm of life that is increasingly increasing. Urban people who feel they have no time to cook themselves because of their busyness often use fast food restaurant services. This is the highest rated fast food restaurant in Indonesia, KFC 55.5 percent, McDonald's 27 percent, HokaHoka Bento 5.8 percent, and Pizza Hut 4.8 percent [1].

But behind all that success, there are serious threats both from consumer behavior and its own competitors, where competition is becoming increasingly fierce and consumers are more health conscious [2]. This is indicated by the decline in profits in 2018, although in terms of revenue, there has been an increase [3].

Improvements in service can be a new breakthrough that can maintain fast food fried chicken restaurant competitive advantage in the future. According to the Nielsen report quoted by Forbes, $92 \%$ of people trust the word of mouth recommendations from friends. According to the report, WOM is a determinant of success in attracting new customers [4]. To get a positive WOM, you must first have a WOM intention.
This is obtained from uniting physical products and services. WOM intention is determined by food quality, personal interaction, physical environment quality, perceived value, customer experience, trust, and commitment [5].

This research was conducted on fast food fried chicken restaurant consumers in Jakarta by taking into account the influencing factors such as Food Quality, Personal Interaction Quality, Physical Environment Quality, Perceived Value, Word of Mouth Intention, Customer Experience, Trust and Commitment.

\section{LITERATURE REVIEW}

\section{A. Food Quality}

Customers with higher familiarity are more likely to consider core cues, such as food quality, directly relevant to restaurants [6]. Food quality is generally accepted as a fundamental element of the overall restaurant experience. Literature reviews reveal that the general explanation of food quality among researchers focuses on taste, variety, healthy choices, presentation, freshness, and temperature [7]. Presentation refers to how interesting food is served and decorated as a tangible sign of customer quality perception [7].

\section{B. Personal Interaction Quality}

Personal Interaction Quality as the ability to deliver products or services accurately and exactly as expected [8]. The more communication between customers and service providers, the less risk is felt in collaboration with purchases for customers. The ability of service providers to communicate with customers increases cooperation and trust during the relationship building process [9]. Thus, good communication has a strong and positive influence on the relationship between restaurants and their customers.

\section{Physical Environment Quality}

Physical Environment Quality is all the physical environment that is around the company such as decoration, atmosphere conditions, comfort, the benefits obtained by consumers when delivering products or services. Factors that 
determine Physical Environment Quality are decoration, ambience conditions, consumer comfort when visiting restaurants [10].

\section{Perceived Value}

Perceived value is the difference between evaluating potential customers of all benefits and all costs incurred with what is felt [11]. The role of the assessment of perceived value is to create a desire from within consumers to continue to buy products or services [12].

\section{E. Customer Experience}

Customer experience is direct and indirect experience in the service process, organization, facilities, and how consumers interact with the services owned by the company with other consumers [13]. Customer experience is a rational and emotional bond that occurs due to the response to certain stimuli by optimizing sense (sensory), feel (emotional), think (cognitive), act (action), and relate (relationship) in marketing efforts before and after purchase, exchange of information and emotional ties [14].

\section{F. Trust}

Trust as self-confidence that arises from within the consumer to the reliability of a brand of product or service and the risk received by consumers after buying a brand of product or service [15]. Trust is formed through Reliability, Honesty, Competence, Orientation and Friendlines.

\section{G. Commitment}

Customer commitment is a desire to maintain the relationship of consumers to service providers. He stated the importance of managing the relationship between consumers and companies in marketing relations [16]. In commitmenttrust theory, there are five factors that determine the trust and commitment of consumers, namely exchanging values, communication, behavior, confidentiality, and security [17].

\section{H. WOM Intention}

WOM intention or word of mouth communication is a communication that contains giving recommendations individually or in groups of a product or service that aims to provide information [18]. This communication is one type of communication that is often used by companies because of communication and word of mouth (WOM) is considered effective to expedite the marketing process and be able to provide benefits to companies and consumers.

\section{RESEARCH HYPOTHESIS}

This research is a replication study using Jalilvand's research [5] as the main reference with the research of $[10,14,19,20]$ as supporting research. Based on the research above, the research hypothesis is as follows:
The better quality of food consumed by consumers can create positive behavior and satisfaction from within consumers after visiting the restaurant can create a positive experience that is owned by customers of the restaurant he visited [6]. Then the research hypothesis can be formulated as follows:

H1: There is an effect of food quality on customer experience.

Employees who have a good psychological and personality when interacting with consumers make consumers have a positive response to products or services sold by restaurants and cause satisfaction because all their desires are fulfilled can create a positive experience that is owned by customers for the restaurant he visited [18]. Then the research hypothesis can be formulated as follows:

$\mathrm{H} 2$ : There is the influence of personal interaction quality on customer experience.

The better design, comfort conditions, and decoration of the restaurant make consumers want to re-visit the restaurant in the future can create a positive experience that the customer has for the restaurant he visits [19]. From these results the research hypothesis can be formulated as follows:

H3: There is an effect of physical environment quality on customer experience.

All assessments of the usefulness of the products or services sold by the company can make customers have a positive feeling when visiting restaurants [21]. Then the research hypothesis can be formulated as follows:

H4: There is an effect of perceived value on customer experience.

The positive reaction that is owned by consumers to the performance of restaurants makes consumers confident of all actions taken by employees who work in restaurants can create a positive experience that is owned by customers for the restaurant he visited [21]. Based on the above research, the research hypothesis can be formulated as follows:

\section{H5: There is an effect of customer experience on trust.}

Positive assessment from within the consumer on the performance of the restaurant can create the desire of consumers to maintain good relations with the restaurant can create a positive experience that is owned by the customer towards the restaurant he visited [14]. Based on the research results above, the research hypothesis can be formulated as follows:

H6: There is an effect of customer experience on commitment.

Consumer confidence in restaurants can overcome the risks that arise when purchasing products or services so as to create a mutually beneficial relationship between consumers and restaurants can create a positive experience that is owned by 
the customer of the restaurant he visited [22], then it can be hypothesized as follows:

\section{H7: There is an influence of trust on commitment}

Consumers who have positive ratings after consuming food sold by restaurants make consumers want to tell something positive to others about the restaurant they visit can create positive experiences that customers have for the restaurant they visit [23]. Then the research hypothesis can be formulated as follows:

H8: There is an effect of customer experience on word of mouth intention

Consumers who are confident with the results obtained when visiting a restaurant make consumers want to provide recommendations to other consumers to continue to visit the restaurant can create a positive experience that is owned by the customer for the restaurant he visited [9]. Then the research hypothesis can be formulated as follows:

H9: There is an influence of trust on word of mouth intention

The desire of consumers to establish good relations with restaurants makes consumers compelled to say anything positive about the products or services sold by restaurants can create a positive experience that is owned by customers for the restaurant they visit [24]. Then the research hypothesis can be formulated as follows:

H10: There is an influence of commitment on word of mouth intention

\section{METHODS}

The sampling method used in this research is purposive sampling. The selected sample is consumers at fast food fried chicken restaurant in Jakarta. The research sample of 217 respondents. The variables used in this study are: (1) Food Quality, (2) Personal Interaction Quality, (3) Physical Environment Quality, (4) Perceived Value, (5) Customer Experience, (6) Trust, (7) Commitment, (8) WOM Intention. For the purposes of quantitative analysis in this study, respondents' answers can be given a score of five Likert Scale ( 1 = strongly disagree, 2 = disagree, $3=$ disagree, $4=$ agree, and $5=$ strongly agree).

\section{RESULTS AND DISCUSSION}

\section{A. Results}

Below is the SEM estimation results on table 1:

TABLE I. SEM ESTIMATION RESULTS

\begin{tabular}{|c|c|c|c|c|c|c|c|}
\hline \multicolumn{3}{|c|}{ Path Analysis } & Estimate & S.E. & C.R. & P-Value & Information \\
\hline C_Experience & $<--$ & Food_Quality & 0,614 & 0,152 & 4,047 & 0,000 & Significant \\
\hline C_Experience & $<--$ & PI_Quality & 0,059 & 0,114 & 0,518 & 0,605 & Not Significant \\
\hline C_Experience & $<---$ & PE_Quality & $-0,051$ & 0,101 & $-0,509$ & 0,611 & Not Significant \\
\hline C_Experience & $<--$ & P_Value & 0,301 & 0,112 & 2,687 & 0,007 & Significant \\
\hline Trust & $<--$ & C_Experience & 0,819 & 0,090 & 9,103 & 0,000 & Significant \\
\hline Commitment & <--- & C_Experience & 0,558 & 0,121 & 4,599 & 0,000 & Significant \\
\hline Commitment & $<--$ & Trust & 0,424 & 0,109 & 3,888 & 0,000 & Significant \\
\hline WOM_I & <--- & C_Experience & $-0,109$ & 0,117 & $-0,933$ & 0,351 & Not Significant \\
\hline WOM_I & $<---$ & Trust & 0,202 & 0,105 & 1,926 & 0,054 & Not Significant \\
\hline WOM_I & $\begin{array}{l}<-- \\
\end{array}$ & Commitment & 0,688 & 0,141 & 4,891 & 0,000 & Significant \\
\hline
\end{tabular}

\section{B. Discussion}

Hypothesis 1. Processing results obtained an estimated coefficient of 0.614 , which means an increase in food quality will increase customer experience and conversely a decrease in food quality will reduce customer experience. With a p-value of $0,000<0.05, \mathrm{t}$ statistic is 4.047 , which means that Ho is rejected (Ha accepted) so that it is proven that the effect of food quality on customer experience is proven significant.

Hypothesis 2. Processing results obtained an estimated coefficient of 0.059 , which means an increase in Personal Interaction Quality will increase customer experience and conversely a decrease in Personal Interaction Quality will reduce customer experience. With a $\mathrm{p}$-value of $0.605>0.05, \mathrm{t}$ statistic of 0.518 which means that Ho failed to be rejected $(\mathrm{Ha}$ rejected) so that the influence of personal interaction quality on customer experience was not proven significant.
Hypothesis 3. Processing results obtained an estimated coefficient of -0.051 , which means increasing Physical Environment Quality will increase customer experience and conversely decreasing Physical Environment Quality will decrease customer experience. With a p-value of $0.611>0.05$ and a t-statistic of -0.509 , which means that Ho fails to be rejected (Ha is rejected) so that the influence of Physical Environment Quality on customer experience is not proven significant.

Hypothesis 4. Processing results obtained an estimated coefficient of 0.301 , which means an increase in perceived value will increase customer experience and conversely a decrease in perceived value will decrease customer experience. With a p-value of $0.007<0.05$ and a statistical t of 2.687 which means that Ho is rejected (Ha accepted) so it is proven that the 
effect of perceived value on customer experience is proven significant.

Hypothesis 5. Processing results obtained an estimated coefficient of 0.819, which means increasing Customer Experience will increase trust and conversely decreasing Customer Experience will reduce trust. With a p-value of 0,000 $<0.05$ and a statistical $t$ value of 9,103 which means that Ho is rejected (Ha accepted) so that it is evident that the influence of customer experience on trust is proven significant.

Hypothesis 6. Processing results obtained an estimated coefficient of 0.558 , which means an increase in Customer Experience will increase commitment and conversely a decrease in Customer Experience will decrease commitment with a p-value of $0,000<0.05$ and $t$ statistic of 4,599 which means Ho is rejected (Ha accepted) so it is proven that the influence of customer experience on trust is proven significant.

Hypothesis 7. The results of the processing obtained an estimated coefficient of 0.424 which means an increase in trust will increase commitment and conversely a decrease in trust will decrease commitment with a p-value of $0,000<0.05$ and a statistical t of 3,888 which means Ho is rejected (Ha accepted) so it is proven that the influence of trust on commitment proved significant.

Hypothesis 8. Processing results obtained an estimated coefficient of 0.109 , which means increasing Customer Experience will not increase WOM Intention and conversely decreasing Customer Experience will increase WOM Intention negative. With a $p$-value of $0.351>0.05$ and a statistical $t$ value of -0.933 , which means Ho failed to reject (Ha rejected) so that the influence of Customer Experience on WOM Intention was not proven significant.

Hypothesis 9. Processing results obtained an estimated coefficient of -0.109 which means that increasing trust will not increase WOM Intention and conversely decreasing trust will not decrease WOM Intention. With a p-value of $0.351>0.05$ and a statistical $t$ value of -0.933 , which means Ho failed to reject (Ha rejected) so that the influence of Trust on WOM Intention was not proven significant.

Hypothesis 10. Processing results obtained an estimated coefficient of 0.688 , which means an increase in Commitment will increase WOM Intention and conversely a decrease in Commitment will decrease WOM Intention. With a p-value of $0,000<0.05$ and a statistical $t$ value of 4.891 which means that Ho is rejected (Ha accepted) so it is proven that the positive influence of the Commitment on WOM Intention is proven significant.

Overall, there are a number of points that can be discussed: As long as the food is delicious and has added value, fast foot fried chicken customers still get a good experience when visiting the restaurant. For fast food fried chicken consumers in Jakarta, food quality is more important than just discounts or low prices. This can be seen from the beta value of $\mathrm{H} 1$ which is greater than the beta value of $\mathrm{H} 4$. The quality of personal interaction and the quality of the physical environment must be increased, a low beta value indicates that there is no visible correlation between the two vectors and the customer experience.

The H5-H7-H10 pathway is the main pathway, namely the formation of WOM intention internally through customer experience, trust, commitment and ultimately to WOM intention Lane H6-H10 is a secondary path this path is a shortcut in the formation of commitments. Commitment can be formed from daily habits. While for line 1, it takes a long time to build relationships with customers but the relationships created will be more lasting and sustainable when compared to relationships formed from line 2. The influence of trust and customer experience on WOM intention must be increased again because the results of $\mathrm{H} 8$ and $\mathrm{H} 9$ are not significant.

\section{CONCLUSION}

Based on the findings and testing of hypothesis described in the previous chapter, the following conclusions can be drawn from the results of this study (1) food quality has a positive and significant effect on customer experience; (2) the quality of personal interaction does not have a positive and significant influence on customer experience; (3) the quality of the physical environment does not have a positive impact on customers; (4) perceived value has a positive effect on customer experience; (5) customer experience has a positive influence on trust; (6) The positive effect of customer experience on commitment is significant; (7) The positive effect of trust on commitment is significant; (8) The influence of Customer Experience on WOM Intention is not significant; (9) The influence of Trust to WOM Intention is not significant (10) The effect of Commitment to WOM's Intentions is significant.

\section{REFERENCES}

[1] Databoks, "KFC Lebih Tenar Dibandingkan Pizza Hut," [online] retrieved from https://databoks.katadata.co.id/datapublish/2016/09/05/kfc-lebih-tenardibandingkan-pizza-hut

[2] M.R. Marwan, "Bahaya makan terlalu banyak makanan restoran cepat saji," [online] retrieved from http://news.gunadarma.ac.id/2017/05/bahaya-makan-terlalu-banyakmakanan-restoran-cepat-saji/

[3] A. Dwijayanto, "Pendapatan naik, tapi laba Fast Food Indonesia (FAST) malah turun di kuartal III-2018," [online] retrieved from: https://investasi.kontan.co.id/news/pendapatan-naik-tapi-laba-fast-foodindonesia-fast-malah-turun-di-kuartal-iii-2018

[4] M. Navani, "Why word of mouth is an effective marketing strategy," [online] retrieved from https://www.forbesmiddleeast.com/innovation/opinion/why-word-ofmouth-is-an-effective-marketing-strategy

[5] M.R. Jalilvand, S. Salimipour, M. Elyasi, and M. Mohammadi, "Factors influencing word of mouth behaviour in the restaurant industry," Mark Intell Plan, vol. 35, no. 1, pp. 81-110, 2017.

[6] J. Ha and S.C. Jang, "Perceived values, satisfaction, and behavioral intentions: The role of familiarity in Korean restaurants," Int J Hosp Manag., vol. 29, no. 1, pp. 2-13, 2010. 
[7] J. Reece, J. Kivela and R. Inbakaran, "Consumer research in the restaurant environment, Part 1: A conceptual model of dining satisfaction and return patronage," Int J Contemp Hosp Manag., vol. 11, no. 5, pp. 205-22, 1999.

[8] O.I. Moisescu and O.A. Gică, "The impact of service quality on customer behavioral loyalty in the case of travel agencies from Romania," Amfiteatru Econ., vol. 16, no. SpecialIssue. 8, pp. 1191-204, 2014.

[9] S. Ng, M.E. David and T.S. Dagger, "Generating positive word-ofmouth in the service experience," Manag Serv Qual, vol. 21, no. 2, pp. 133-51, 2011.

[10] K. Ryu, H.R. Lee and W.G. Kim, "The influence of the quality of the physical environment, food, and service on restaurant image, customer perceived value, customer satisfaction, and behavioral intentions," Int J Contemp Hosp Manag., vol. 24, no. 2, pp. 200-23, 2012.

[11] P. Kotler, K.L. Keller, Manajemen Pemasaran, Edisi 13. Jilid 1. Cetakan Keempat, Jakarta: PT Indeks, 2013.

[12] D. Gill, B. Byslma, and R. Ouschan, "Customer perceived value in a cellar door visit: The impact on behavioural intentions," Int J Wine Bus Res., vol. 19, no. 4, pp. 257-75, 2007.

[13] R. Garg, Z. Rahman and M.N. Qureshi, "Measuring customer experience in banks: scale development and validation," J Model Manag., vol. 9, no. 1, pp. 87-117, 2014.

[14] J. Hwang and S. Seo, "A critical review of research on customer experience management: Theoretical, methodological and cultural perspectives," Int J Contemp Hosp Manag., vol. 28, no. 10, pp. 2218-46, 2016.

[15] J.E. Haefner and A. Rosenbloom, "In Consumer Decision Making: Insights from Bulgarian and Hungarian Consumers During the Global
Economic Crisis," Manag Glob Transitions vol. 9, no. 3, pp. 249-73, 2011.

[16] G. Fullerton, "The Impact of Brand Commitment on Loyalty to Retail Service Brands," Can J Adm Sci / Rev Can des Sci l'Administration, vol. 22, no. 2, pp. 97-110, 2005.

[17] R.M. Morgan and S.D. Hunt, "The commitment-trus theory of relationship marketing," J Mark., vol. 58, no. 3, pp. 20-38, 1994.

[18] R.J. Ferguson, M. Paulin and J. Bergeron, "Customer sociability and the total service experience: Antecedents of positive word-of-mouth intentions," J Serv Manag., vol. 21, no. 1, pp. 25-44, 2010.

[19] M. Zhang, M. Hu, L. Guo, and W. Liu, "Understanding relationships among customer experience, engagement, and word-of-mouth intention on online brand communities: The perspective of service ecosystem," Internet Res. vol. 27, no. 4, pp. 839-57, 2017.

[20] S. Chou and C.W. Chen, "The influences of relational benefits on repurchase intention in service contexts: the roles of gratitude, trust and commitment," J Bus Ind Mark, vol. 33, no. 5, pp. 680-92, 2018.

[21] S.M.C. Loureiro, F.J. Miranda, and M. Breazeale, "Who needs delight?: The greater impact of value, trust and satisfaction in utilitarian, frequentuse retail," J Serv Manag., vol. 25, no. 1, pp. 101-24, 2014.

[22] I. Volkmer, "The Handbook of Global Media Research," The Handbook of Global Media Research, 2012.

[23] A. Triantafillidou, and G. Siomkos, "Consumption experience outcomes: satisfaction, nostalgia intensity, word-of-mouth communication and behavioural intentions," J Consum Mark, vol. 31, no. 6/7, pp. 526-40, 2014.

[24] M. Shirkhodaie, M. Rastgoo-deylami, "Positive Word of Mouth Marketing: Explaining the Roles of Value Congruity and Brand Love," J Compet., vol. 8, no. 1, pp. 19-37, 2016. 